\title{
Legal Protection of Property Rights in the Self-Regulating United States Local Recording System
}

\begin{abstract}
Introduction
Private property rights are among the most cherished values in the United States. Their enforceability is essential for commercial, industrial, and agricultural development and long-term capital investment. They are also important to everyday life. About two-thirds of Americans live in a home that they own, and millions of single-family homes are built and purchased annually. ${ }^{1}$ Real estate investment and finance are at the core of the national economy, and disruptions in the real estate market can have a worldwide impact.

A reliable public real estate recording system is vital for private property ownership and the formation of capital for economic development. ${ }^{2}$ In all countries with private property, the recording system has three main purposes: to give reliable information about ownership rights, to prevent fraud, and to minimize transactional costs. ${ }^{3}$ Unlike in most countries, in the United States the government does not play a central function in achieving these purposes. While the local government register of deeds maintains a system of public information about ownership rights, the parties to a transaction are solely responsible for the reliability of that information, and they must rely on due diligence and private insurance to minimize the risks of fraud.
\end{abstract}

\section{Evolution of Self-Regulating System}

The real estate conveyance recording system in the United States can trace its origins back four centuries to the English settlements. The first office of a register of deeds on

$1<$ https://www.nar.realtor/research-and-statistics/quick-real-estate-statistics $>$.

2 H. De Soto, The Mystery of Capital: Why Capitalism Triumphs in the West and Fails Everywhere Else, "Basic Books", New York 2000, p. 149.

3 A. Garro, Recordation of Interests in Land, in: Encyclopedia of Comparative Law Vol. VI Ch. 8, ed. A. N. Yiannopoulos, Tübingen 2004, p. 4. 
the continent was in Plymouth, Massachusetts, which provided a book for recording a land transfer. ${ }^{4}$ The Massachusetts law that required such recording is fundamentally the same as the laws in each state today. State law establishes a local government register of deeds, an office that enables private parties to confirm the rights of someone offering to sell and to protect themselves against wrongful claims by recording their instruments. ${ }^{5}$

State laws all provide that when an instrument has been recorded with a register of deeds, it gives "constructive notice" to the world. This means that everyone is bound by what is contained within the instrument regardless of actual knowledge. Consequently, a purchaser or lender has the burden of searching the records and assessing the nature of ownership title to ensure the seller can convey the rights being promised. In most states, the register is an elected local government official. ${ }^{6}$

Only Hawaii and Alaska, the newest states, have a centralized state recording system with local branch offices. All registers record instruments sequentially as they receive them, and they maintain an index for public search. These records are fully available to anyone during office hours, and increasingly they are publicly accessible on the Internet. Anyone may record instruments with a register of deeds provided the submissions meet certain format requirements and all applicable recording fees are paid. ${ }^{7}$ This open system contrasts with the more restricted access that is typical in other countries. Even in the English system, from which the United States system emerged, the law provides that "no person other than the owners of the record of estates and interests are permitted to inspect the land records". ${ }^{8}$

In the United States, the rights that follow from recording are determined by state law. State laws give certain priorities to those who first record their interests in the registries. Someone who fails to record risks having someone else acquire a superior right by recording the conveyance first. The most common type of statute is known as a "racenotice" statute. For example, a Massachusetts law provides that a conveyance "shall not be valid as against any person, except the grantor or lessor, his heirs and devisees and persons having actual notice of it, unless it ... is recorded in the registry of deeds for the county or district in which the land to which it relates lies". ${ }^{9}$ This means that a purchaser must both record and lack actual knowledge of a prior conveyance to be protected against someone else who obtains and records a deed claiming the same property. A few

4 J. Beale Jr., The origin of the system of recording deeds in America, "The Green Bag" 1907, no. 19, pp. 335-339.

5 C. Szypszak, Local Government Registers of Deeds and the Enduring Reliance on Common Sense Judgment in a Technocratic Tide, "Real Estate Law Journal" 2015, no. 44, p. 352.

6 Ibidem, pp. 352-363.

7 E. Roscoe, C. Szypszak, Privacy and Public Real Estate Records: Preserving Legacy System Reliability Against Modern Threats, "The Urban Lawyer" 2017, no. 49, pp. 362-364.

8 A. Garro, op. cit., p. 102.

9 Massachusetts General Laws. ch. 183, § 4 (2011). 
states have a statute that is known as a "race" system, which is characterized simply as "first to record, first in right." For instance, a North Carolina statute provides that no instrument of conveyance "shall be valid to pass any property interest as against lien creditors or purchasers for a valuable consideration, but from the time of registration thereof in the county where the land lies". ${ }^{10}$ This has been interpreted to mean that those who record first will have title even if they knew someone else was already conveyed the same property. However, even in the few states with this type of race recording statute, in some circumstances the courts will not allow the statute to protect a party based on general equitable principles. ${ }^{11}$

These priorities based on recording entail several kinds of risk. Owners and lenders are left to their own resources for searching the records and understanding their legal significance. This involves careful use of indexes, and an ability to interpret real estate instruments, most of which are not required to be in any form other than what is acceptable to the particular parties to them. The system also involves what is known as "off-record" risks that cannot be found at the registry, such as forgeries or claims based on actual use of the property. These risks, to some degree, are due to the nature of the unique self-regulating recording system. In essence, those acquiring property interests must protect themselves-it is a "user beware" system ${ }^{12}$.

This system has persisted despite efforts to change it into something more like systems in other countries. More than a century ago, some policy makers were concerned about how the risky existing recording system might impair real estate development, and they looked to adopt a registration system based on the Australian method devised by Sir Robert Torrens, which he modeled on how ships were registered. In the Torrens system, a public official examines applications for transfers of title and issues a certificate of ownership if everything is in order. The Torrens system also typically provides a government guaranty to reimburse someone deprived of a property interest if registration incorrectly describes the property or wrongfully gives ownership to another. Twenty-one states in the United States enacted some type of Torrens registration process. ${ }^{13}$ However, this registration approach quickly ran into legal trouble. In 1896, one year after Illinois enacted a Torrens-type system, in People v. Chase $(1896)^{14}$ the Illinois Supreme Court declared the law to be unconstitutional because it gave the registers of deeds powers to determine property rights, which only a judge can do in the United States system of separation of powers. Courts in other states had similar views about

10 North Carolina General Statutes Annotated, 2017, § 47-18(a).

11 C. Szypszak, North Carolina's Real Estate Recording Laws: The Ghost of 1885, "North Carolina Central Law Journal" 2006, no. 28, pp. 212-216.

12 C. Szypszak, Public Registries and Private Solutions: An Evolving American Real Estate Conveyance Regime, "Whittier Law Review" 2003, no. 24, pp. 668-670.

13 R. R. Powell, Powell on Real Property, New York 2014, p. 83.01[3], 83-5 to 83-7.

14 People v. Chase, 46 N.E. 454 Ill. 1896. 
the unconstitutionality of having a register of deeds declare ownership. Legislatures responded by requiring a court decree before property could be registered, which made the system much more cumbersome and costly than the Australian model. ${ }^{15}$

The Torrens assurance fund, which is intended to compensate for loss resulting from improper registration, also proved ineffective in the United States. No recovery from a fund would be allowed unless the harmed party first sought recovery from someone who caused the harm through fraud, negligence, or other wrongdoing. Consequently, unless the loss is due solely to registration error, collection from the fund will necessarily entail litigation with another private party-just as in the usual system. The notion of state payment for loss of title also was not supported with realistic funding resources. In California, the statewide fund became bankrupt, leading to the repeal of Torrens registration in that state, and in Nebraska, assurance fund solvency problems led to abandonment of the system. ${ }^{16}$ The emptiness of this type of financial guaranty is not unique to the United States. Claims against such a fund are rare in other countries as well. ${ }^{17}$

The Torrens system's limitations under American law and public policy resulted in its complete abandonment in most of the states that adopted it, and very infrequent use in the others. In those states that enacted Torrens systems, registration is optional. An advocate for Torrens registration called it the "most infrequently used method of land conveyancing in the United States". ${ }^{18}$ In practice, Torrens registration appeals to some commercial interests in unusual circumstances, such as urban redevelopers who need to establish boundaries in areas subject to prior survey discrepancies, and timber companies who want to be certain about ownership of large tracts before cutting the timber. However, the cost and delay of a court proceeding, and the absence of any guaranty, make it unattractive for most transactions. ${ }^{19}$

\section{Public Officials and Private Risk}

As described above, in the race-notice or race recording system in the United States, real estate recording is not just a matter of memorializing an event. It legally operates to establish rights. Consequently, a failure to record promptly and properly can have severe consequences, including the loss of ownership or the inability to enforce a mortgage loan against the property.

15 C. Szypszak, Public registries..., pp. 673-682.

16 B. C. Schick, I. H. Plotkin, Torrens in the United States, Lexington 1978, pp. 63-64.

17 A. Garro, op. cit., p. 125.

18 J.V.B. II, Yes Virginia - There is a Torrens Act, "University of Richmond Law Review"1975, no. 9, p. 301.

19 C. Szypszak, Public Registries..., pp. 680-682. 
In most countries, the public official responsible for land registration acts as a gatekeeper, ensuring that those who record have the right to do so, and that they record instruments in a proper form. ${ }^{20}$ Registers of deeds in the United States do not check to see whether someone recording a document has a legitimate interest in the rights it describes, or whether the conveyance complies with any applicable regulations. One reason why the American real estate conveyance system is so efficient is that the parties are free to structure and consummate their arrangements without need for government review or approval. Parties are left to protect themselves with legal advisors, who perform due diligence in title searches, and with private assurance mechanisms, principally title insurance. The vast majority of both residential and commercial transactions occur in this system without any title problems. ${ }^{21}$

Registers do not entirely ignore the instruments presented to them. To discourage false filings, they check submissions for some evidence of authentic execution before recording. ${ }^{22}$. The signing of real estate instruments in the United States usually involves a notary public, just as they do in other countries. American notaries are commissioned by state authorities and take an oath to follow the law. ${ }^{23}$ Unlike in most other countries, they play a very limited role. In essence, they observe someone's signature and complete a certificate on the instrument to record this event. They are prohibited from drafting or completing the instruments, ${ }^{24}$ and they do not record them.

In their limited review of authenticity, registers of deeds check to see that signatures on deeds and mortgages have been notarized in this manner. They do this only by looking for the signature and seal of the notary, not by checking the notaries' commissioning status. ${ }^{25}$ In many cases, the register will be unfamiliar with the notary and have no way to know if the person in fact is currently commissioned, nor is there any independent record by which to confirm the notary's capacity or notarial act. The formality is some disincentive to fraud or hasty filings that cause problems, but of limited use in protecting against fraud.

The extent to which the system relies on self-regulation rather than any public official's involvement can be seen with how the excise tax on conveyances typically is imposed and collected in in the United States. For example, North Carolina's tax, is $\$ 1$ on each $\$ 500$, or part thereof, of the amount paid for the property. ${ }^{26}$ Registers do not

20 A. Garro, op. cit, pp. 101-103.

21 C. Szypszak, Real Estate Records, the Captive public, and Opportunities for the Public Good, "Gonzaga Law Review", 2007, no. 43, p. 16.

22 C. Szypszak, Local government ..., pp. 363-364.

23 North Carolina General Statutes Annotated, 2017, § 10B-3(13).

24 North Carolina General Statutes Annotated, 2017, § 20(k).

25 C. Szypszak, North Carolina Guidebook for Registers of Deeds, "Chapel Hill, NC: UNC School of Government", 2016, pp. 111-129.

26 North Carolina General Statutes Annotated of 2017. 
investigate the economic reality of the transaction. They rely on the person who presents the instrument for recording to state the amount paid for the property on which the tax is based. ${ }^{27}$ The register of deeds puts a stamp on the instrument in the public record to show the amount paid. Officials in other countries may be incredulous that this kind of an honor system could function. Yet there is widespread compliance, in large part because parties realize that the amount of the tax, shown on the public record, is a representation about the value of the property. They may have difficulty later explaining the property value when looking to sell to a purchaser or to obtain a mortgage loan if they originally misreported the value when they paid the tax.

\section{The Parties' Professionals}

Given the very limited role played by public officials in a land transaction in the United States, the parties must rely on other professionals to consummate a real estate transaction in a way that protects their rights. Most transactions involve two professionals: brokers and attorneys.

No law in the United States requires anyone to hire a broker to sell or to buy real estate, but there are more than two million licensed real estate professionals and about nine out of ten home sales involve a broker. ${ }^{28}$ Most parties to sales view brokers as a valuable source of information about the property because of their knowledge of the local market. State laws require individuals to be licensed before they may represent someone as a broker. ${ }^{29}$ State commissions have education and examination requirements, rules for representing clients, and procedures for complaints and discipline including loss of license. A broker owes a fiduciary duty to the client, which means the broker must act in the client's best interest. As the court instructed in Clouse v. Gordon (1994) ${ }^{30}$, brokers can be responsible for fraud or misrepresentation only if the broker actively conceals known material facts. Brokers do not have an obligation to investigate property conditions for the parties.

Most brokers work for sellers and are paid by them, even when they deal with buyers. The amount of the typical commission is substantial, usually between five and eight percent of the sale price. Brokers therefore have strong financial incentive to consummate a sale and to demonstrate value of their service through efficient management of

27 National Conference of State Legislatures, 2018

28 <https://www.nar.realtor/research-and-statistics/quick-real-estate-statistics>.

29 North Carolina General Statutes Annotated, 2017, § 93A-1.

30 Clouse v. Gordon, 115 N.C. App. 500, 445 S.E.2d 4281994. 
the transaction. Their desire to be perceived as instrumental in the process also is incentive to resist any changes in the system that would diminish their role. ${ }^{31}$

United States law similarly does not require any party buying or selling real estate to hire a lawyer for the transaction, but most parties do engage lawyers. There is no standard fee for routine matters such as preparing a deed, doing title work, and handling a closing, but fees tend to be similar for such services within a community. In a typical transaction, the lawyer's fee is much less than one percent of the purchase price.

Drafting legal instruments is the practice of law and it can only be done for someone by a lawyer licensed within the state. Lawyers-or someone under their supervision-confirm the rights of the seller and ensure proper instruments are recorded. One of the most important functions for which parties rely on lawyers' expertise is the search of the public records to determine the validity of the seller's interests. Unlike most countries that have tract indexes-in which a searcher can see all of the ownership information pertaining to a particular parcel by looking up the parcel number-most jurisdictions in the United States use a grantor-grantee index. Parties must rely on their professionals' ability to find all records that convey interests in any particular parcel of real estate. This requires linking current and historical owner names in the operative instruments of conveyance, which is known as developing the "chain of title." In most states, the lawyers' professional association publishes title examination standards as guidance for how to conduct such a search. ${ }^{32}$ Most searches can be done within a few hours if there is an unbroken chain to the current owner for the length of a reasonable search period-something like thirty years of ownership, which depends on local custom and the requirements of the title insurance company.

These professionals face free-market incentives to provide reliable advice at a competitive price. One remarkable feature of this system is that if the parties are motivated to close a transaction quickly, these professionals can get it done within hours, without need for awaiting any government approvals in connection with instrument recording.

\section{Title Insurance}

Unlike countries that provide government assurances of title, in the United States a system emerged in the form of private title insurance. Title insurance developed with the

31 C. Szypszak, Real Estate Records, the Captive Public, and Opportunities for the Public Good, "Gonzaga Law Review”,2007, no. 43,pp.16-18; A. M. Olazábal, Redefining Realtor Relationships and Responsibilities: The Failure of State Regulatory Responses, "Harvard Journal on Legislation"2003, no. 40 , p. 65.

32 R. B. Johnson, Basic Principles of Title Examination for the General Practitioner, "The Practical Lawyer"1961, no. 7, pp. 39-45. 
mortgage lending market. As described above, the Torrens system available in other countries did not succeed in the United States. Purchasers and lenders needed a different standardized and practical method of obtaining indemnity against loss, and the title insurance industry developed as a relatively efficient and reliable means to assure lenders that the borrower can give a valuable mortgage interest in real estate title as security for the loan. Title insurance also proved important in the development of the secondary mortgage market, enabling loan originators to package their mortgages with title insurance policies that are transferable, and giving investors standardized institutional protection of mortgage enforceability based on title. ${ }^{33}$ These developments led to widespread reliance on title insurance to the point where, in the words of a federal court in Schwartz v. Commonwealth Land Title Insurance Company (1974) ${ }^{34}$, "it is a matter of common knowledge and experience that in the usual situation, title insurance is indispensable to the occurrence of the real estate sale: a seller would be unable to sell his property at its reasonable value if no title company was willing to insure title."

Title insurance is usually a relatively small cost in conveyances. The total charge for title search and the issuance of a policy is around one percent of the property's price. A onetime insurance premium is paid for coverage during the full length of ownership, which protects against certain claims in connection with title to the property. ${ }^{35}$ Once issued, a title insurance policy provides protection against a variety of risks such as a claim to title based on actual possession and lack of its marketability due to an adverse claim based on title. A title insurance policy is a contract, and the title insurance company's obligations are defined by the terms of the policy. State regulators require title insurance companies to file their policies and rates, but the precise terms of coverage are determined in the competitive market of insurance companies. ${ }^{36}$

Before issuing a policy, the title insurance agent, who is a lawyer, searches the records and determines the nature of the title. The insurance is not intended to be a means for owners and lenders to obtain indemnity against known title problems or risks that cannot be avoided based on examination of the title records. Coverage will not be provided over an identified problem unless the insurer determines the risk is small enough to accept or other protections are provided, such as indemnity is obtained from another party. Standard policy language excludes a number of risks from coverage, such as the effects of land use regulations, bankruptcy, or government expropriation. Additionally, by their terms owners' policies usually do not cover several categories of matters that are not disclosed in the registry records. As a federal court said in Schwartz v. Commonwealth Land

33 C. Szypszak, Public Registries and Private Solutions: An Evolving American Real Estate Conveyance Regime, "Whittier Law Review" 2003, no. 24, pp. 682-692.

34 Schwartz v. Commonwealth Land Title Insurance Company, 374 F. Supp. 564, 574 E.D. Pa. 1974.

35 C. Szypszak, Public registries ..., p. 684.

36 C. Szypszak, Public registries ..., pp. 682-692. 
Title Insurance Company (1974) $)^{37}$, "title insurance companies are only liable for what they do not find, or if they become victims of false affidavits tendered to remove title objections. Against this background it would be in our view unrealistic, indeed ostrich-like, to separate the title search process from the pure insurance aspect of the title insurer's activities ..."

Although title insurance will not cover title problems that are known, those who purchase policies benefit from the insurer's incentive to identify risks. In essence, title insurance is more risk prevention than risk assumption. ${ }^{38}$ With most forms of insurance, such as health insurance, insurance companies use much of the policy premiums they collect to pay for insureds' claims. Title insurance is fundamentally different. Title insurers pay a very small part of their premiums to customers who suffer losses due to a covered matter. The majority of the premiums are retained by the lawyer who searches the title before issuing a policy, reflecting the preventative nature of the policy issuance process. Surveys indicate that about one-third of real estate closings reveal a title issue that is discovered in this process, most commonly the need to confirm that a prior mortgage has been paid and is no longer effective, or for unpaid taxes. ${ }^{39}$ These kinds of problems are addressed by the parties before the policy is issued. In other words, getting the policy results in the problems being resolved before the owner takes title and the lender closes the mortgage loan. Based on losses reported to state insurance regulators, title insurers pay out only about three percent of their revenue for losses to insureds. ${ }^{40}$

Even in unusual circumstances in which title problems went undetected and claims are made, title insurers often can cure the problems by obtaining instruments that can be recorded, such as when mortgages had been paid but no records were filed that the mortgages are no longer enforceable. Title insurers also often can solve problems by negotiating with those who have competing claims, or if necessary with litigation.

\section{Modern Threats from Frivolous Liens}

The unregulated nature of the recording system in the United States leaves open a threeheaded threat: the difficulty of identifying instruments that are illegitimate; the ease with which information about ownership can be learned by someone seeking to cause harm; and the ease with which such a fraudulent or frivolous filing can be made.

37 Schwartz v. Commonwealth Land Title Insurance Company, 374 F. Supp. 564, 574 E.D. Pa. 1974.

38 C. Szypszak, Public registries..., pp. 688-692.

39 J.W. Eaton, D.J. Eaton, The American Title Insurance Industry: How a Cartel Fleeces the American Consumer, New York, 2007, pp. 18-19.

40 Ibidem, pp. 71-72. 
The nature of these threats has changed in recent years due to greater complexity in secured real estate financing. Most real estate transactions are residential conveyances for which lenders use standard, federally approved forms. However, a chief virtue of the system is that the parties are left to draft their instruments in any way that meets their transactional objectives, and registers of deeds do not have legal authority to impose any uniformity requirements. Even the standard loan transactions increasingly now involve legal instruments that the normal person would not understand. This is in large part due to the secondary mortgage market, in which mortgage loans are assigned to securitized trusts. Most owners are not even aware that their loans are held in these pools or that assignment instruments are recorded for them-their loans are managed through a servicing company, which remains the same even as the loan is transferred in the secondary market. In fact, most residential mortgage loans in the United States are now held in the name of the Mortgage Electronic Registration Systems, Inc. ("MERS"), a nominee to which the loan is assigned and by which it is held as the real interest in the loan is transferred. This minimizes transaction costs by eliminating the need to record assignments every time the loan changes hands. As a result, very few owners would be able to tell whether a strange financial instrument is for a legitimate mortgage transfer arrangement or is being filed by someone trying to cause harm with a frivolous document. ${ }^{41}$

There is no simple remedy if someone files a frivolous document. The law in the United States has always enabled owners to seek a court order declaring a recording void, and such an order can be recorded with the register of deeds to clear the title issue. This may not be an efficient remedy, however, because harm may have already occurred resulting from delay upon detecting the fraudulent instrument. Those who file fraudulent documents also are subject to criminal prosecution for a number of crimes, including statutory and common law fraud, as well as violation of laws specifically aimed at fraudulent liens. Although this may punish the wrongdoing, it will not address the costs to the owner for dealing with the delay and otherwise having to clear problems caused by the frivolous filing.

Those who depend on the existing system's openness and efficiency-lenders, attorneys, brokers, and title insurers-want to preserve the system's core features. Some policy makers see openness as enabling fraud, and they look to restrict access to the public real estate records. For example, Florida statutes now enable law enforcement officers, judges, states attorneys and a number of other public officials and their families to request redaction of their home addresses from the public records, including real estate records. ${ }^{42}$ However, restricting access can effectively make the records less complete and reliable, while not entirely preventing wrongdoers from getting the information they seek because other public sources of information are available. For example, much informa-

41 E. Roscoe, C. Szypszak, Privacy and Public Real Estate Records: Preserving Legacy System Reliability Against Modern Threats, "The Urban Lawyer” 2017, no. 49, pp. 364-368.

42 Florida Statutes Annotated of 2017. 
tion is contained in local real estate tax records. In the United States, local government taxes real estate within its jurisdiction, and, for billing and collection purposes, it tracks and publishes owners' names and addresses. Most local governments now make this information available through their websites with searchable databases. To some degree, availability of this information is constitutionally necessary-taxes must be proportional, so owners must be able to compare the tax valuation of their property to the valuation of other properties. As long as this information must remain open, limiting access to conveyance records offers little protection. ${ }^{43}$

Other states have enacted measures that do not restrict access to the system but instead attempt to give affected owners earlier notice of a potential problem. The laws governing real estate recordings already require some types of information to be disclosed when an instrument is filed. For example, state laws typically require the buyer's address be on a deed, which is used for real estate tax billing. ${ }^{44}$ Others require a deed to identify the person who drafted it, which is used to create an obstacle to the unauthorized practice of preparing a deed for someone else without being a licensed lawyer. ${ }^{45}$ Similarly, states may require some form of notice to be given to an owner when an instrument is recorded that has the apparent characteristics of a fraudulent lien. This is similar to the procedure in some civil law countries such as Switzerland that require the recorder to notify owners if someone attempts to make an entry in the land register without the owner's knowledge. ${ }^{46}$ In the United States, Texas law authorizes the registering official to send notice to a person named in an instrument if the register has a reasonable belief that the instrument submitted for filing is fraudulent. ${ }^{47}$ The procedure is not entirely reliable, because the register must first detect the attempted fraud, which is difficult in a United States system that does not require instruments to be in any certain form. Private companies also have begun to offer such services, by which they scan the electronic versions of the open public records and provide notice to customers that something with their names has been filed. This is similar to the credit monitoring services provided from major credit bureaus.

Regardless of what minor requirements may be enacted, the continued reliability of the self-regulated recording system largely depends on the due diligence and judgment of those who rely upon it. Success in causing harm with frivolous filings depends on the reaction of those who view the instrument during a pending transaction. The filer of a harmful instrument wants buyers and lenders to delay or withdraw out of concern that the filing could be enforced against the property. In most cases, this intent can be defeated if the party

43 E. Roscoe, C. Szypszak, Privacy and public..., pp. 374-378.

44 New Hampshire Revised Statutes Annotated of 2016.

45 North Carolina General Statutes Annotated of 2017, § 47-17.1.

46 Swiss Civil Code of 2012, Code of Obligations, § 969.

47 Texas Government Code of 2016. 
who finds the instrument treats it for what it is worth-nothing legitimate-which in most cases should be readily apparent, rather than make hasty decisions that turn a frivolous filing into something with a real impact.

Methods also exist for owners to put a layer of legal protection between themselves and the public records of ownership by using traditional ownership forms that individuals can create with standard organizational filings. Owners can take title in the name of an entity or trustee that will appear as the current owner in the register's index and in the public tax records. Two common entity forms in which an individual can hold sole ownership are corporations and limited liability companies, each of which allow use of a fictitious name adopted upon formation. ${ }^{48}$ Another common ownership form is a trust, which technically is not a legal entity, but rather an agreement between someone transferring property to another-the trustee-with direction about how the property is to be held and transferred. Those who benefit from the trust-the beneficiaries-need not be disclosed in the real estate filings. ${ }^{49}$ Use of such techniques adds a layer of confidentiality, but it does not prevent someone who understands entities and trusts from doing off-record investigation to find out who holds the ownership interests in them.

\section{Conclusion}

The recording system in the United States enables sellers, buyers, and lenders to consummate property transfers efficiently and without any need for government approval or involvement. They rely on an open local government register of deeds system that has remained fundamentally the same despite changes in the nature of real estate transactions and threats to its reliability. Purchasers and lenders can protect against risks involved in this conveyancing system with their own due diligence and responsibility, including engaging professionals to perform expert research to verify claims of ownership and assess risks, and arranging for insurance against the possibility of major loss. Though this system shares many of the functions found in other countries, it is unique in the passive nature of government's involvement.

48 Model Business Corporations Act of 2016; Revised Uniform Limited Liability Company Act of 2006.

49 Uniform Trust Code of 2010. 


\section{Literature}

Beale Jr. J., The Origin of the System of Recording Deeds in America, "The Green Bag",1907, no. 19.

De Soto H., The Mystery of Capital: Why Capitalism Triumphs in the West and Fails Everywhere Else, New York, 2000.

Eaton J.W., Eaton D. J., The American Title Insurance Industry: How a Cartel Fleeces the American Consumer, New York 2007.

Garro A., Recordation of Interests in Land. in: ed. Athanassios N. Yiannopoulos, "Encyclopedia of Comparative Law", Vol. VI, Ch. 8, Tübingen 2004.

J.V.B. II, Yes Virginia - There is a Torrens Act, "University of Richmond Law Review" 1975, no. 9.

Johnson R. B., Basic Principles of Title Examination for the General Practitioner, "The Practical Lawyer", 1961, no. 7.

Olazábal A. M., Redefining Realtor Relationships and Responsibilities: The Failure of State Regulatory Responses, "Harvard Journal on Legislation”, 2003, no. 40.

Powell R. R., Powell on Real Property, New York 2014.

Revised Uniform Limited Liability Company Act $\S \S 105,108,201,209$ (2006).

Roscoe E., Szypszak C., Privacy and Public Real Estate Records: Preserving Legacy System Reliability Against Modern Threats, "The Urban Lawyer” 2017, no. 49.

Schick B. C., Plotkin I. H., Torrens in the United States, Lexington 1978.

Schwartz v. Commonwealth Land Title Insurance Company, 374 F. Supp.564,574 (E.D. Pa. 1974).

Szypszak C., Local Government Registers of Deeds and the Enduring Reliance on Common Sense Judgment in a Technocratic Tide, "Real Estate Law Journal" 2015, no. 44.

Szypszak C., North Carolina Guidebook for Registers of Deeds, "Chapel Hill, NC: UNC School of Government" 2016.

Szypszak C., North Carolina's Real Estate Recording Laws: The Ghost of 1885, "North Carolina Central Law Journal", 2006, no. 28.

Szypszak C., Public Registries and Private Solutions: An Evolving American Real Estate Conveyance Regime, "Whittier Law Review" 2003, no. 24.

Szypszak C., Real Estate Records, the Captive Public, and Opportunities for the Public Good. "Gonzaga Law Review" 2007, no. 43. 
22 | Adam Mickiewicz University Law Review

SUMMARY

\section{Legal Protection of Property Rights in the Self-Regulating United States Local Recording System}

In all legal systems with private property, the government provides a mechanism for owners and lenders to make a public record of their rights. In most countries, the government restricts access to this public record and allows entries into it only after a public official approves it. By contrast, no government entity in the United States regulates, confirms, or guarantees the typical real estate ownership transfer. How this works is not readily understood even within the United States, where owners and lenders rely on attorneys and other professionals to examine and understand the public record and to record instruments that protect their clients' property rights. This article describes the laws and legal customs that underlie this self-regulating system, including how they differ fundamentally from land registration in other countries, and the emerging challenges to its reliability.

Keywords: property rights, land recording, registers of deeds, real estate conveyances.

Charles Szypszak, Albert Coates Distinguished Professor of Public Law and Government, University of North Carolina at Chapel Hill, Campus Box 3330, UNC Chapel Hill Chapel Hill, NC 27599-3330 United States of America, e-mail: szypszak@sog.unc.edu. 